\section{EARTHQUAKES IN NEW ZEALAND}

A

VERY important review of New Zealand earthquakes by Dr. J. Henderson, director of the Geological Survey of New 7 ealand, and Mr. R. C. Hayes, acting-director of the Dominion $\mathrm{Ob}$ servatory, Wellington, New Zealand, has been issued*. Compared with other countries in which earthquakes are common, the frequency of earthquakes in New Zealand is relatively high. This is due to the occurrence of a large number of semi-destructive earthquakes and comparatively few major destructive earthquakes. During the years 1835-1934, there were 69 New Zealand earthquakes, of which 6 reached intensity 10 on the Rossi-Forel scale, 14 attained intensity 9 on the same scale, and the remainder were of smaller intensity. During the twenty years from 1921 until 1940 inclusive there has been an average of approximately 260 earthquakes felt in the islands each year, the average maximum intensity of the greatest shocks being rather more than 8 (semi-destructive) on the RossiForel scale. During the year 1922 there were 1,187 earthquakes felt, but this abnormally large number was due to the Taupo earthquake swarm. The aftershocks of the Buller earthquake of June 17, 1929 , also caused the total numbers in 1929 and 1930 to be greater than normal.

New Zealand may be divided roughly into four seismic regions:

(I) All areas of the North Island east and south of an approximate line from the vicinity of Whakatane in the Bay of Plenty to the vicinity of Hawera, in South Taranaki, and all areas of the South Island north of an approximate line from the vicinity of Hokitika on the west coast, through the region of Lake Coleridge, to Banks Peninsula. During the years $1921-40$ this region had an average of $97 \cdot 8$ earthquakes per year, $4 \cdot 1$ per decade of which were semi-destructive, and 1.7 per decade destructive (R.F. 9-10).

(2) South Auckland, western Bay of Plenty, Waikato, and Taranaki (except the southem portion). During the years 1921-40 there was an average of 23 earthquakes per year, of which $1 \cdot 1$ per decade were of intensity R.F. 8 (minor destructive) and there was none of greater intensity. The activity in this region tends to increase gradually towards the east and south, where it merges into region 1 .

(3) Areas of the South Island, south of the boundary of region 1 . In this region between 1921 and 1940 there were $12 \cdot 1$ earthquakes per year, of which 0.1 per decade were semi-destructive (R.F. 8), and none of greater intensity. Only one semi-destructive shock has been definitely recorded in this region (near Mount Cook), though early history suggests that heavy shocks occurred in the West Coast Sounds region in the years $1792,1810,1826-27$. The eastern side is definitely less seismic than the western.

(4) Areas north of Auckland. In this region during the years 1921-1940 there was an average of $1 \cdot 1$ earthquakes per year, of which none reached intensity 8 on the Rossi-Forel scale. No destructive shocks have been known to occur in this region.

It is emphasized that these regions are approximate and that one region merges into its neighbours.

* "Earthquakes in New Zealand". Dominion Observatory, Wellington, W.1, New Zealand. Bulletin No. S. 63, extracted from the "New Zealand Official Year-Book, 1942".
Taken in conjunction with the geology of New Zealand, the above facts are most instructive, and apart from the geology they can scarcely be compre. hended. Earthquake and volcanic activity are manifestations of the adjustments constantly occurring in the earth's crust. Around the great sunken area of the Pacific there is a more or less continuous belt of geologically recent mountains, and this belt as a whole is subject to "chronic and acute seismicity". Earthquakes sometimes happen within the belt itself, though a large proportion have their epicentral areas on its submerged frontal slope. Dr. Henderson states that the South Island of New Zealand and the eastern part of the North Island are on the crest of the great mountain ridge or crustal fold which forms a portion of the real border of the Pacific. This ridge maintains a relatively straight course north-north-east for 1,600 miles across the floor of the Pacific, nearly to Samoa. The Auckland Peninsula, part of a decidedly weaker fold, meets the main fold nearly at right angles in the RotoruaTaupo volcanic region. The earthquakes of this seismically sensitive district, though they may be locally severe, are not usually felt far from their points of origin. On the other hand, the tectonic earthquakes that occur along the main earth-fold shake large areas, some of them being recorded on instruments throughout the world. These are caused by slipping of earth-blocks against their neighbours along fractures.

Many great fault-zones have been traced for long distances, but a few only have been active since European occupation. The Hawke's Bay earthquake of 1931 raised an area 60 miles long and in parts 10 miles wide in a north-east direction. The uplift was greatest along the south-east edge of the area, for miles amounting to $6 \mathrm{ft}$. or more. Numerous levels on the Heretaunga Plain and along the railway north of Napier showed that the uplift decreased northwestward, so that the area was slightly tilted in that direction. The ground east of the uplifted area sank, and parts of the Napier and Wairoa flats are more than a foot lower than before the earthquake.

In 1929, movement along a north-trending fault seven miles west of Murchison raised the ground east of the fault by about $15 \mathrm{ft}$., and caused it to shift north-west by about $9 \mathrm{ft}$. The uplift gradually decreased eastward and died out sixteen miles from the fault, facts indicating a slight tilt of the earthblock towards the east. Subsequent levellings showed that the block was sinking somewhat irregularly, a movement, no doubt, which caused some of the innumerable local after-shocks felt in the area over many months after the main shock.

Other sensible earth-movements occurred in connexion with the Taupo earthquake series of 1922 , the Amuri earthquake of 1888, the Wellington earthquake of 1855, and probably the Awatere earthquake of 1848. There is also definite evidence of geologically recent differential movement of earth-blocks at several widely separated points in both Islands. Seismographs situated at Wellington, Auckland, Christchurch, Arapuni and New Plymouth registered four strong distant earthquakes during July 1942 (Provisional Bulletin, No. P 125). These were on July 7 , 8, 25 and 29. Additionally there were nineteen sensible shocks in the islands, none being greater than intensity 4 on the Rossi-Forel scale. The greatest of these was on July 26 and was felt with intensity 4 (R.F.) in the western areas of North Island and the northern parts of the South Island. 